\title{
ライフサイクルと微細なかたちに魅せられて
}

\author{
野崎久義 \\ 東京大学大学院理学系研究科生物科学専攻 干113-0033 東京都文京区本郷7-3-1
}

要旨：生殖を繰り返して形態が変化し，また同じステージに戻る「ライフサイクル」は生物の基本的で興味深い特性で ある。筆者が淡水産緑藻を研究材料にした理由は, これらは培養が容易でライフサイクルの研究が実験室で可能だっ たからである。本稿では筆者がこれまでに継続してきた淡水産藻類のライフサイクルと微細なかたちに関する研究内 容を紹介する。前世紀に著者が実施した数多くの群体性ボルボックス目を対象とした光学顕微鏡レベルのライフサイ クルの研究成果は, その後に我々が形態・遺伝子・ゲノムデータを用いて実施した系統解析, 性特異的遺伝子および 多細胞化の研究を触発し, 礎となった。一方, 単細胞性緑藻 Carteria, 灰色藻 Cyanophora と Glaucocystis の電子顕微鏡 を用いて我々が明らかにした細胞の3 次元立体微細構造は，新たな「微細なかたち」であり，それぞれの属における種 レベルの分類に大きく貢献した。最近のフィールド調查で採取された群体性ボルボックス目の「ミッシングリンク藻 類」はライフサイクルで非常に興味深い形態的特性を示したので, 淡水藻類の形態と多様性に関する分野の今後の発 展には更なるフィールド調查が期待される.

\section{Fascinated by life cycles and micromorphology of freshwater algae}

\section{Hisayoshi Nozaki}

Department of Biological Sciences, Graduate School of Science, The University of Tokyo, Hongo 7-3-1, Bunkyo-ku, Tokyo, 113-0033 Japan

Author for correspondence: H. Nozaki, nozaki@bs.s.u-tokyo.ac.jp

Summary: Organisms exhibit life cycles in which they change their morphological features extensively by means of reproduction. The life cycle is a fundamental and impressive attribute of organisms. Freshwater green algae are very suitable for the life cycle research because methods for cultivation and induction of sexual reproduction have been published in these algae. Here, our previous morphological studies of freshwater algae carried out in these 40 years are reviewed, especially in the life cycle and micromorphology. Results of my light microscopic observations of the colonial volvocalean life cycles in the last century triggered and based our subsequent studies of the phylogeny, sex-specific genes and multicellularity, using the molecular genetic, genome and microscopic data of the colonial Volvocales. In addition, our electron microscopic observations of freshwater green alga Carteria and glaucophytes Cyanophora and Glaucocystis demonstrated their more natural three-dimensional ultrastructural features that contributed much to the species taxonomy of these genera. Since missing link species of the colonial Volvocales recently found from the natural habitats exhibited very interesting morphological features of the life cycle, further field works are very fruitful for future studies of morphology and diversity of the freshwater algae.

Key words: freshwater algae, life cycle, morphology, taxonomy, ultrastructure

はじめに

生物を認識する最も基本的な表現形質の情報は「形態」 である。生物は生殖を通して様々な形態を示す非常に興味 深いものであるので，全ライフサイクルを明らかにして生 物を認識することが生物学の基本である。以上のような考 えを最も容易に研究面で実現できるのが「淡水産緑藻類」 である (市村 1971-1973). 淡水産緑藻類は培養が容易で, 有性生殖を含むライフサイクルを培養条件下で完結するこ こが可能である。このような観点から，筆者は1977年の 学部卒業研究以来淡水産緑藻類のライフサイクルに関する 研究を継続している. 更に, 生物の形態は電子顕微鏡で観 察するとこの世の中にこんな不思議なものがあったかと思 わせる「微細なかたち」の世界に導いてくれる。本稿では 自分自身の 40 年の研究の軌跡を「ライフサイクル」と「微細 なかたち」に焦点古わせて紹介してゆきたい.
1. ライフサイクル : シアワセモとの出会い

学部の卒業研究では緑藻・群体性ボルボックス目のパン ドリナ (Pandorina) の 1 種 P. morum の有性生殖の光学顕微 鏡観察を実施した。有性生殖を誘導して配偶子の接合を観 察することはできたわけであるが, 接合子の発芽に関して は不十分であった。学部卒業後神奈川県の私立大学の付属 高校に勤めたことが，その後の研究人生に大きく影響した。 色々な面で余裕のある職場であり, 理科棟の片隅のスペー スで培養・顕微鏡観察することが許された。 まずは卒業研 究の続きということでP. morum の接合子の発芽に挑んだわ けであるが, 当時の論文情報 (Coleman 1959) では短期間 (3 日間) の暗処理で未熟な接合子発芽させるというもので あつた。この方法を日本産の材料で実施してみたもののう まくゆかず，成熟した接合子で 1 ケ月以上の暗処理で発芽 した (Nozaki and Kasaki 1979).

その後，成熟した接合子を用いた，長期間暗処理の発芽 
法を基本的に用いて様々な群体性ボルボックス目のライ フサイクルを完結した (野崎 1986)。その中で特に苦労を したのがシアワセモ (Tetrabaena socialis) であった. 1982年, 当時の勤務先の高校の裏の小さな池から採取した泥を乾か し, 再び水を注ぐと泳ぎだして来たものが 4 細胞性の遊泳 する緑藻であった (図1A), 当時,「シアワセモ」という和 名はなく，16細胞性の種がほとんぞのゴニウム(Gonium) という属に含まれていた (Stein 1959)。配偶子の接合は窒 素飢餓培地で誘導され，接合突起が片方からだけ伸びる， 群体性のゴニウムやパンドリナには見られないタイプであ つた. しかし，接合子の発芽が 1 ケ月の暗処理では誘導さ

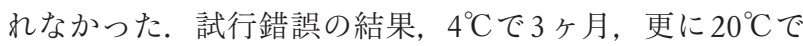
3 ケ月, 合計 6 ケ月の暗処理で通常の明暗培養条件に戻す ことで接合子が発芽した。発芽様式はそれまでに群体性ボ ルボックスには見られないもので，4個の発芽細胞がバラ バラで泳ぎ出ると言うものであった (Nozaki 1986) (図 1BE). シアワセモの配偶子の接合と発芽様式は群体性ボルボ ックス目に近縁なクラミドモナス (Chlamydomonas) の1種 C. reinhardtii と基本的には同じであった. 従って, シアワ セモは有性生殖の形態的形質でも原始的であり, 群体性ボ
ルボックス目で最も初期に分岐した生物であると推測した (野崎 1986).

以上の推測を系統解析から検証するために, 群体性ボル ボックス目の全ライフサイクルデータを用いた分岐系統学 的解析を実施した (Nozaki and Ito 1994). その結果, シア ワセモが最も初期に分岐した系統群に位置すると解析され, 属名もGoniumから Tetrabaena という独立した属に変更した. 葉緑体 5 遺伝子による分子系統学的解析の結果もこれを支 持した (Nozaki et al. 2000). 系統関係がほぼ明らかになつ たので, これに基づき有性生殖の進化の分子基盤を明らか にする研究を目指した. その結果, 群体性ボルボックス目 の雌雄の配偶子をもつプレオドリナ (Pleodorina) から, オ スに特異的な“OTOKOGI” (PlestMID) を発見した (Nozaki et al. 2006). この研究は性特異的遺伝子が位置する性染色体 領域に着目した性進化研究のブレークスルーとなつた (Ferris et al. 2010, Yamamoto et al. 2017, Hamaji et al. 2018).これ らの研究内容の詳細に関しては本雑誌の総説 (野崎 1995a, 2008) や野崎 (2010), 浜地ら (2018) に詳しいので, ここで は割愛する。
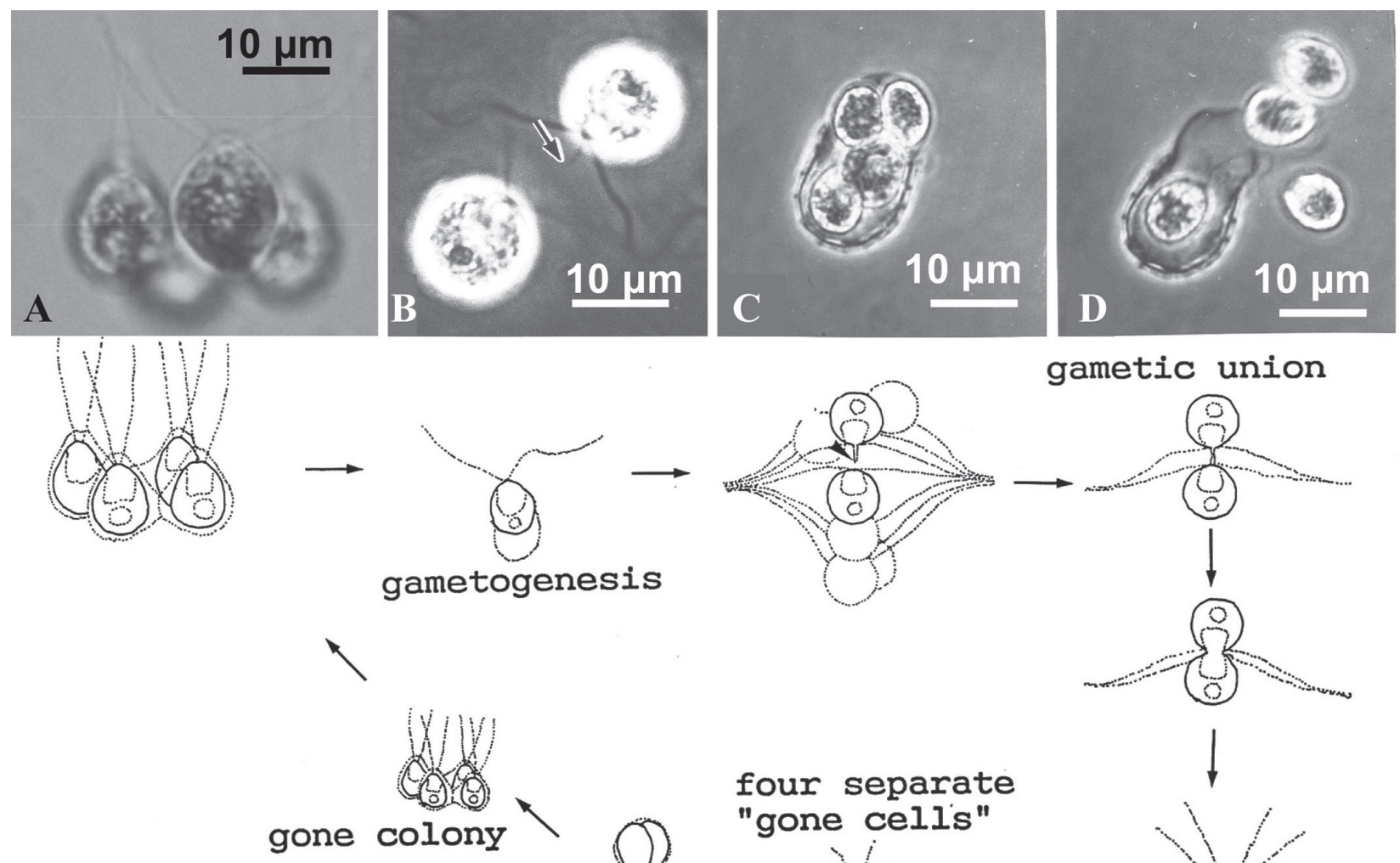

E

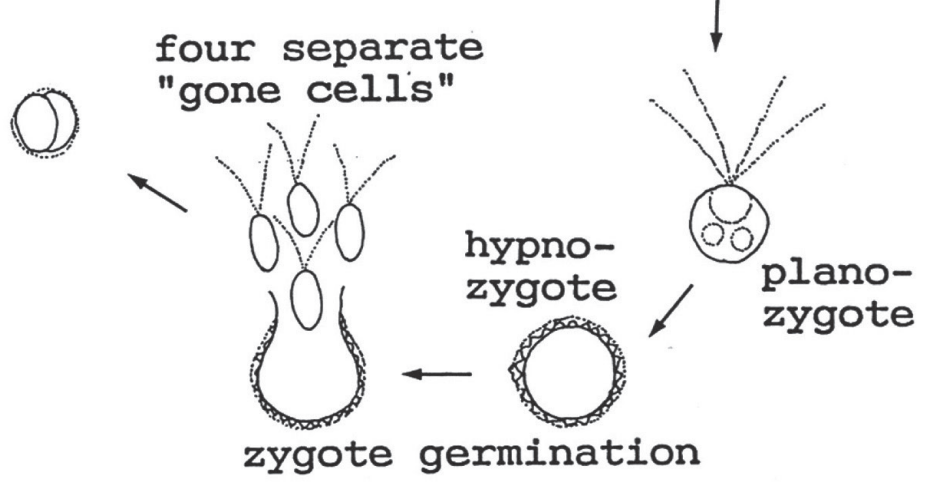

図 1 シアワセモ(Tetrabaena socialis)のライフサイクル(Nozaki 1986). (A) 栄養群体. (B)配偶子の接合. 片方の配偶子だけが接合突起 (矢印) をもつ. (C, D) 接合子の発芽. (E) 模式図. (A) および (E) は著者の原図である. 写真 (B-D) は Nozaki (1986) から転載した。 Phycologia の 転載許可 (Copyright Clearance Centre の License Number 4460240946268)による. 
2. 微細なかたちの集合「多細胞化」:シアワセモとの再会

単細胞が複数集合して，より高次な「かたち」者生み出 す「多細胞化」に関しては，2010年までは群体性ボルボッ クス目を扱う研究者としては「灯台下暗し」であった。
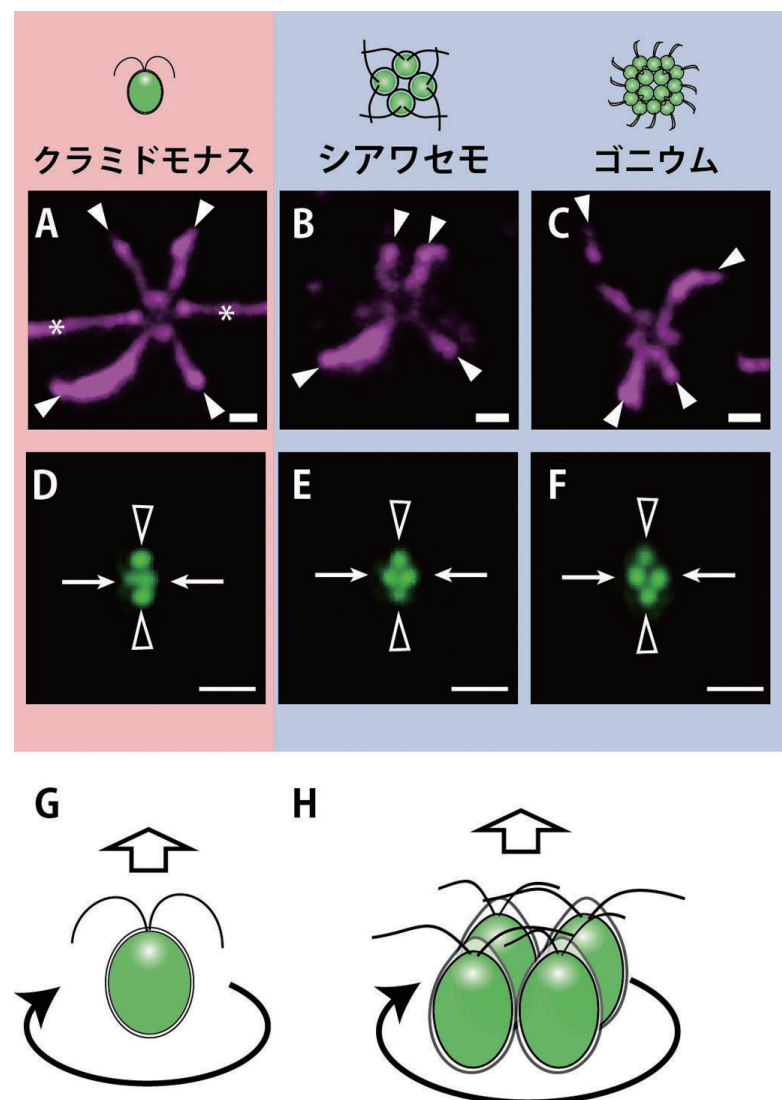

H
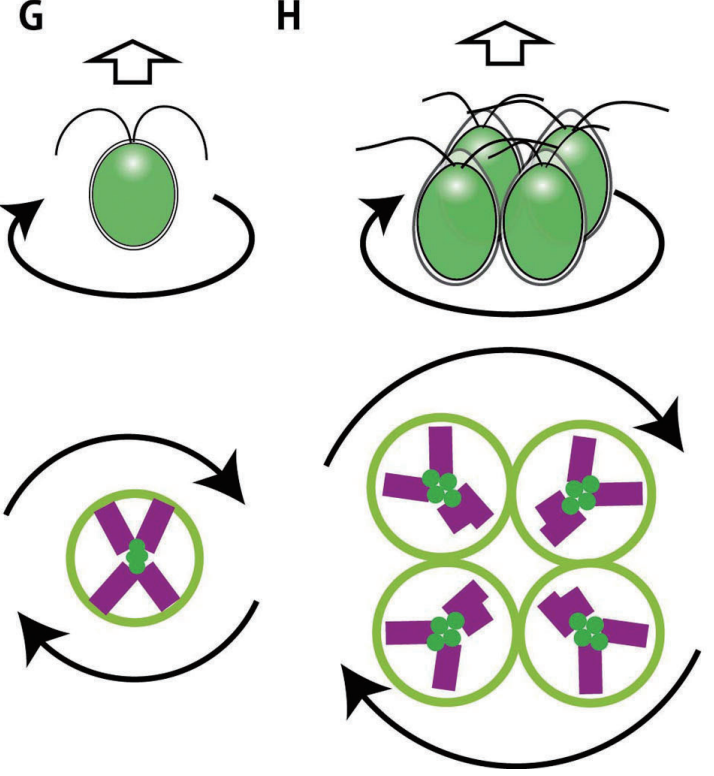

図2 単細胞性クラミドモナス (Chlamydomonas reinhardtii)，4 細 胞性シアワセモ (Tetrabaena socialis)，16細胞性ゴニゥム (Gonium pectorale)の細胞 (Arakaki et al. 2013). スケールバーはすべて $1 \mu \mathrm{m}$. (A-C) 細胞構造を鞭毛側から見た免疫蛍光染色像. 白い矢尻で示 した四方に伸びる赤色蛍光が細胞の中で骨格に相当する鞭毛の根 元から伸びる構造である。(A) クラミドモナス。骨格構造が回転 対称. *印は鞭毛. (B) シアワセモ。骨格構造が非回転対称. (C) ゴニウム。骨格構造が非回転対称. シアワセモとゴニウムは単細 胞性クラミドモナスとは異なる構造を持つ. (D-F) 鞭毛の根元の 免疫蛍光染色像. 鞭毛が生じる基底小体が緑色の蛍光として観察 される。矢印が鞭毛の根元, 黒い矢尻が次世代の鞭毛の根元であ る. (D) クラミドモナス. 鞭毛の根元が近接している.（E）シアワ 七モ。鞭毛の根元が離れている。(F) ゴ二ウム。鞭毛の根元が離れ ている。多細胞化すると集合した細胞全体が個体として運動する ため, 各細胞は単細胞性の生物とは異なる構造を持つようになる. 鞭毛の根元が離れるものその一つと考えられている. (G, H) クラ ミドモナスとシアワセモの細胞構造と回転遊泳の模式図. すべて 新垣陽子博士の原図である。
東日本大震災の直後の 2011 年 4 月, 沖縄から新人の修士 課程 1 年の女子学生新垣陽子さんが野崎研究室にやってき た.「私，ボルボックスの仲間で多細胞化の研究をしたい です.」と主張したので，筆者はこれまで殆ど自分では研究 していなかった内容なので困った，テーマを色々考えた結 果, 思い出したのが「シアワセモ」であった. 本藻類が他 の群体性ボルボックス目とはライフサイクル的にも系統的 にも異なることを主張したのは野崎のグループだけであり, 外国の研究者はあまり着目していなかった。 また, 群体性 ボルボックス目の分岐年代を推定した Herron ら (2009)に よれば, シアワセモが多細胞生物の段階に達していない, 4個の単細胞生物が集合しただけのものと解釈されてい た。従って，我々はまず，シアワセモが多細胞生物である ことを形態学的に証明する観察を実施した (Arakaki et al. 2013). 即ち, シアワ七モの同調培養系在確立し, 細胞内 の微小管を免疫蛍光染色法で観察したところ, シアワセモ は多細胞生物であるゴニウムやボルボックスと同様に非回 転対称な細胞構造を持っており, シアワセモの4 個の細胞 がそれぞれ多細胞個体の一部として機能していることが示 唆された (図2).さらに, 透過型電子顕微鏡 (TEM) を使っ てシアワセモの娘群体の発生中の細胞を観察すると, 娘細 胞同土が原形質間架橋で連絡していることが明らかとなり， 4個の細胞が統合されて決まった形の多細胞体を形作って いることを意味した (図3)。これらの特徴は群体性ボルボ ックス目の細胞数の多いゴニウムやボルボックス等に見ら

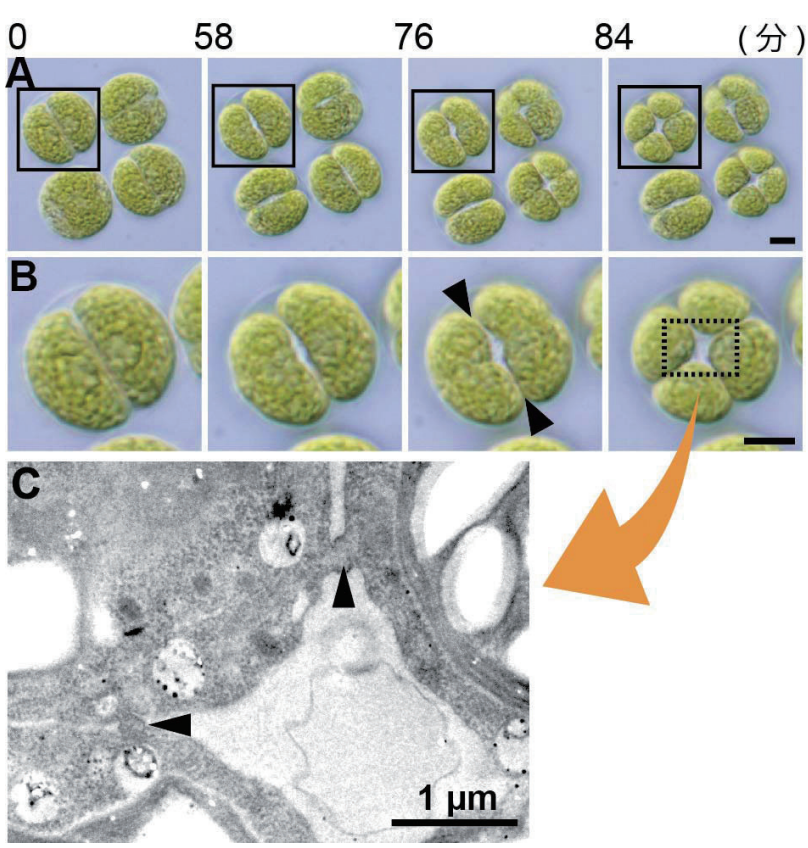

図3 シアワセモ(Tetrabaena socialis) の細胞分裂と発生初期の透過 型電子顕微鏡 (TEM) 像 (Arakaki et al. 2013). (A, B) 同じ細胞を 経時的に観察するための“タイムラプス撮影”した光学顕微鏡像 (Arakaki et al. 2013). シアワ七モの初期発生の細胞分裂の様子が わかる. スケールバーは $5 \mu \mathrm{m}$. 上段の数字は撮影開始からの経過 時間. (A) シアワセモは, 4つの細胞がそれぞれ2回分裂して娘群 体を作る。（B）(A)の黒枠内の細胞を拡大したもの. 娘細胞同士が 矢尻で示した部分で接続していると推測された。 (C) 撮影開始か ら84 分経過した細胞に相当するTEM像. 左上の娘細胞が両隣の 娘細胞と原形質間架橋で連絡している (矢尻)。すべて新坦陽子博 士の原図である。 
れる一般的なものであり, ボルボックス系列 (群体性ボル ボックス目及び単細胞性のクラミドモナス [Chlamydomonas reinhardtii]) の多細胞化の最も初期の 4 細胞の段階で獲得さ れていたと推測された。したがって，4個の細胞から成る シアワセモは, 最も細胞数の少ない多細胞生物であると 結論された，尚，「しあわせ藻” (シアワセモ)」という名前 は, 単細胞生物クラミドモナスに似た細胞が 4 個, 四葉の クローバーの様に細胞壁で結合しており，幸せの象徴であ る四葉のクローバー状の形と, 2 億年前に「幸運にも」多細 胞化したということから, 新垣陽子さんが名付けた (新垣 ら 2013).

我々のシアワセモの研究が 2013 年に発表されると, 南 アフリカの研究グループが興味を持ち, 彼らとの「シアワ セモのゲノム解読による多細胞化」に関する国際共同研究 が開始した. その結果, 群体性ボルボックス目の多細胞化 の最も初期の 4 細胞の段階で細胞周期関連の遺伝子が進化 して多細胞化が起きたことが推測された (Featherston et al. 2018)。これは我々が2016年に発表した 16 細胞性のゴ二ウ ムのゲノム解読で得た結論 (Hanschen et al. 2016) が4細胞 の段階まで引き伸ばされたものであった。

しかし,これらの比較ゲノム生物学的研究は具体的にに゙ のような遺伝子のタンパクの発現が細胞生物学的に变化し, 多細胞化をもたらしているかを示していなかった，従って 我々は細胞質分裂関連の遺伝子に着目した。すでに述べた ように 4 細胞以上のボルボックス系列では連続する細胞分 裂期 (胚発生中) において, 娘細胞同士が原形質間架橋で 互いに連結しており, この連結が将来の多細胞の成熟個体 の種によって決まった「かたち」を作り出している (Arakaki et al. 2013).このような原形質間架橋は細胞質分裂時に細 胞質が完全に分離しない「不完全な細胞質分裂 (incomplete cytokinesis)」によって起きることが示されていたが (Kirk 2005), 細胞質分裂関連の遺伝子に着目した多細胞化の研
究はこれまでになかった。そこで, 陸上植物で細胞質分裂 に関わるとされるダイナミン様タンパク質DRP1 (Hong et al. 2003) に着目し, 単細胞性ボルボックス目のクラミドモ ナスと4 細胞性のシアワセモ, 16細胞性のゴニウムを用い て比較解析を実施した (Arakaki et al. 2017). その結果, 第 二分裂時に単細胞性と多細胞性で DRP1の局在パターンが 異なることが明らかった (図4)。従って, 単細胞性と多細 胞性の生物では細胞質関連遺伝子の振る舞いが異なり, 本 生物群の多細胞生物では不完全な細胞質分裂をもたらして いることが推測された. この研究はボルボックス系列の細 胞質分裂と多細胞性の関連をはじめて分子レベルで示すも のであり, ボルボックス系列における多細胞性の進化を明 らかにする上で, 今後重要な知見となると期待される.

\section{3. 電子顕微鏡が誘う「微細なかたち」の世界}

筆者が群体性の緑藻類を材料とした理由は, 学部の卒業 研究の時に「単細胞性藻類では電子顕微鏡が必要だけぞ, 群体性藻類では分類に必要ないので研究材料にできる」と いうものであった，その結果，「多細胞化と雌雄性の両進 化が同時研究できる群体性ボルボックス目」を扱うことが でき, 上述のような成果がもたらされた。しかし, 電子顕 微鏡には興味があり, 1992 年に国立の研究所 (国立環境研 究所）に勤務することになり，「ようやく単細胞が研究でき る!」と思つた. 最初に手をつけたものが千葉県のサンプ ルから分離・培養した単細胞性緑藻のカルテリア (Carteria) であった．カルテリアは4本鞭毛性の生物で, 千葉県産の 培養株は「鞭毛のない不動配偶子」で接合する興味深いも のだったので (Nozaki 1994), 早速分類学的同定を実施し た (野崎 1995b). 光学顕微鏡で観察すると本藻類のパピラ (鞭毛の根元の細胞壁の突出) がれ型であった (図 5A, B). パピラの形態的特徴は単細胞性ボルボックス目では種以上 のレベルの分類学的に重要な形質であり, これまでに型

\section{Unicellular Chlamydomonas-type}
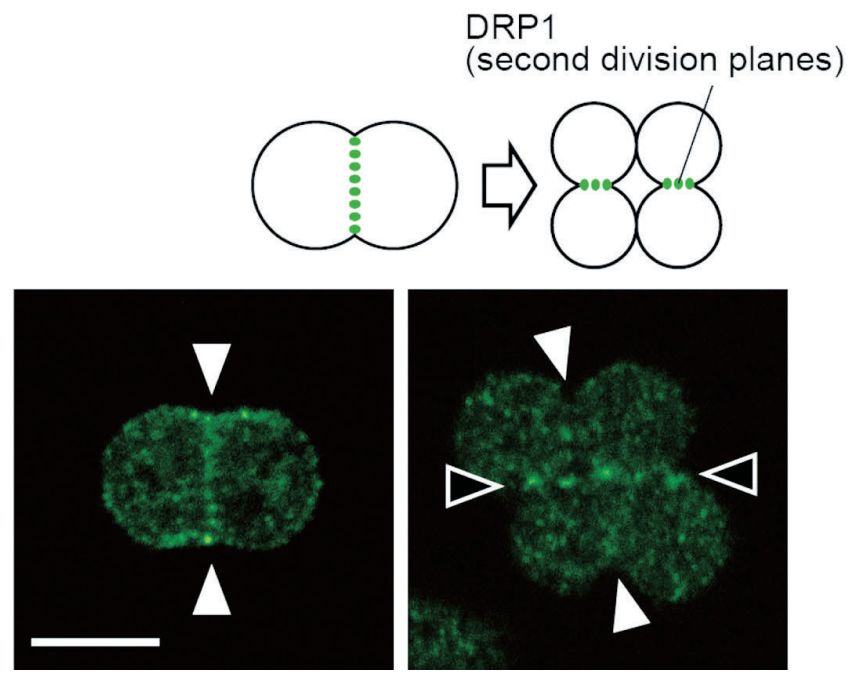

図4 単細胞性クラミドモナス (Chlamydomonas reinhardtii) と4 細胞性シアワセモ (Tetrabaena socialis) では細胞質分裂関連因子DRP1の局在 (緑色) が 4 細胞期で異なる (Arakaki et al. 2017). スケールバーは $5 \mu \mathrm{m}$. 白い矢尻が第 1 分裂面，黒い矢尻が第 2 分裂面を示す。図と写真は Arakaki ら (2017) から転載, 改変した。

\section{Multicellular \\ Tetrabaena/Gonium-type}

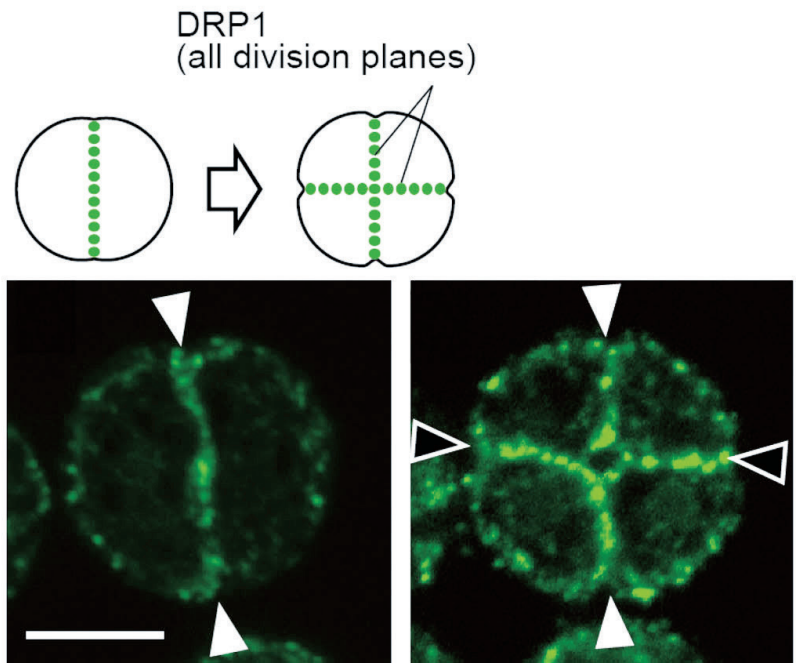


のパピラの種は報告されていなかった。「型パピラの種 の発見だ!」と喜び,「これを走査型電子顕微鏡 (SEM) で 見れば面白い」と思い，币ではないが十字形のパピラを持 つとされているカルテリアの 9 株と共に比較形態学的観察 を実施した，その時, 同じ研究室にSEMの達人 (相澤賢一氏) がいたので非常に助かった。 その結果, 全ての株が币型の パピラをもつことが明らかになり(図5C-F), 千葉県産の 2 株を含む 11 株は光学顕微鏡と透過型・走查型電子顕微鏡 データで4種に再分類された (Nozaki et al. 1994). この分 類は形態データだけによるものだったので, 後に分子系統 解析で検証し，4種は単系統種であることが明らかになっ た (Nozaki et al. 1997)。これを契機に, 微細藻類の種分類 を形態データと分子データの両面から実施し,「単系統形 態種」を基本とする方法論を確立した (Nozaki et al. 1998, 野崎 1998).

単系統形態種で微細藻類を分類することは, 「生物の種 をかたちで認識すべきである」という主張に基づく。しかし， 分子系統では多くの系統に分かれるが，形態的には識別さ れない「隠蔽種」が多くの藻類群に存在する。その最たる ものが, 灰色藻類 (glaucophytes) であつた。

灰色藻類は 10 億年程前の太古の植物形態を未だ留め ているとされ,「生きた化石」とも称される一次植物の 珍しい1群である。本藻類の単細胞の遊泳性キアノポラ (Cyanophora) 属のC. paradoxa と群体性の不動性グラウコシ シティス (Glaucocystis) 属の G. nostochinearumではそれぞれ 分子系統では明らかに複数の種レベルの単系統群から構成 されているが, 種として識別する形態的形質が認められな いとされていた (Chong et al. 2014). 我々は多くの培養株 老用いて, 光学顕微鏡 超高分解能電界放出形走査電子顕 微鏡 $(\mathrm{FE}-\mathrm{SEM}) \cdot \mathrm{TEM} に よ る$ 比較形態及び分子生物学的手 法を併用し, 従来 C. paradoxa とされていた培養株を細胞 形状に基づき, 新種 C. cuspidata Tos.Takah. \& Nozaki, 新種 C. kugrensii Tos.Takah. \& Nozaki, C. paradoxaの 3 種に分類し た (Takahashi et al. 2014)。この成果は細胞壁を欠くキアノ ポラ属の細胞表層の立体構造を FE-SEMで詳細に観察でき たことによるが, 厚い細胞細部壁構造をもつグラウコシシ ティス属の細胞表層の立体微細構造はFE-SEMでは観察で
きない.そこで我々はグラウコシシティス属の種を細胞表 層の立体微細構造で分類する目的で超高圧電子顕微鏡観察 を実施した。その結果，G. nostochinearum と従来同定され ていた培養株に細胞表層と母細胞壁の立体微細構造におけ る多様性が認められ, 分子系統解析の結果越ま沓ま, 培養 株は6形態種に再分類された (Takahashi et al. 2016). 従つ て, これまで形態的には分類できないとされている微細藻 類の多くの隠蔽種も最新の形態観察手法を用いれば形態種 とし認識される可能性が十分あると言える。以上の「キア ノポラ属」の種分類と灰色藻類の細胞表層の立体微細構造 から推測された「最初の一次植物の微細なかたち」に関し ては本雑誌の別の総説（高橋と野崎 2016）で詳しく解説さ れているので, 参照して下さい.

\section{4. ミッシングリンク藻類を求めて}

多様性生物学を長年やっていて, 最も興味深いのは進化 上重要と考えられる「ミッシングリンク」の発見である.

群体性ボルボックス目は多細胞化や有性生殖の進化を研 究する上で格好の生物群である。この中のボルボックス科 は, 娘群体形成初期に典型的な反転 (inversion) を行うこ とと, 群体全体を包む連続した細胞壁構造をもつことを特 徴としている (Nozaki and Kuroiwa 1992)。この科に含ま れる藻類の内, パンドリナやボルボックス (Volvox) 等の群 体は回転棈円体であるが, プラチドリナ(Platydorina) 1 属 だけ平板状の群体を持っている (Nozaki and Ito 1994). 我々が 2000 年から実施している葉緑体 5 遺伝子系統解析に より, 群体性ボルボックス目の基本的な系統関係が明らか にされた一方, プラチドリナの姉妹群については不明であ つた (Nozaki et al. 2000).

埼玉県川越市の伊佐沼は, 仲田崇志博士が野崎研の大 学院生であった時に地図を頼りにして探し出した「ボルボ ックス目の穴場」である. 次々に新種 (Volvox ferisii, Isaka et al. 2012), 日本新産 (Pascherina tetras, Sugasawa et al. 2015) が採取されている。従って, 野崎研究室の分類学を志す 学生は伊佐沼の調査は必須である. 2005 年頃野崎研究室 に所属していた山田敏宽氏は伊佐沼の 32 細胞性の群体性 ボルボックス目の1株が形態的にはユードリナ (Eudorina)
A
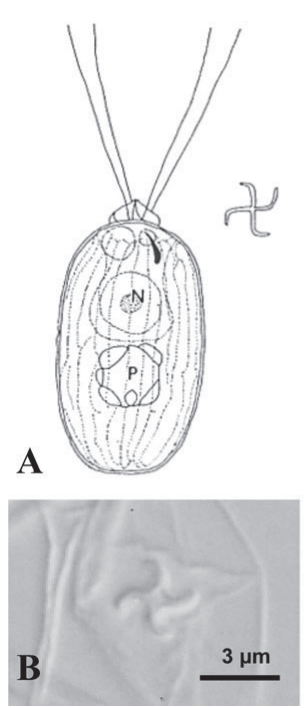
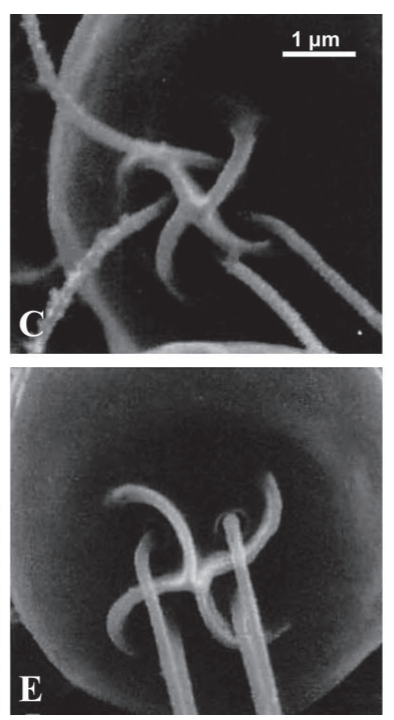
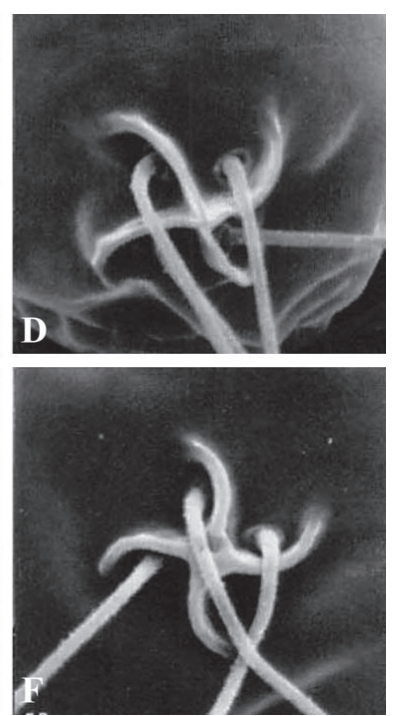

図 5 让型のパピラを持つカルテリア (Carteria). (A, B) 光学顕微鏡観察による千葉県産の培養株 (Nozaki et al. 1944). B は原形質を除いた細胞 壁を観察している. (C-F) 走査型電子顕微鏡で 観察した4種のパピラ。同一倍率である。(C) C. crucifera. (D)C. engametos. (E)C. inversa. (F) C. cerasiformis. (A) および (C-F) はNozaki ら (2014)より転載した. Phycologia の転載許可 (Copyright Clearance Centre $の$ License Number 4460240644063）による.（B）は著者の原図であ る. 
やヤマギシエラ (Yamagishiella) と類似しているが(図6A), 分子系統解析するとこれらとは異なる系統的位置であっ た. 研究室ではこの不思議な藻類を通称 “Yamadiella” と呼 んでいた。しかし, “Yamadiella”の有性生殖は不明で, 山 田氏が修士課程を卒業したあとは, 培養株 1 株が置き去り にされた状態であった. その後, 時々 “Yamadiella” は採取 され，2010年7月採取の培養株は精子束 (紡錘形のオス配 偶子の群体) が形成されたが，接合は観察されなかった。 “Yamadiella” は伊佐沼に同時に発生するユードリナと採取 したサンプルで区別するのが困難であるため，10株以上 培養株を確立した後, この中から“Yamadiella”選抜する 必要があった。ところが, 2013 年6月のサンプルは普段と は異なっており，確立した株がほとんど “Yamadiella”であ つた。「これだけあればメスとオスがあり，混合すれば有 性生殖が誘導できる。まず，「3株以上混ぜてみよう.」と 思い, 培養株を遠心濃縮後, シャーレで混合してプレオド リナ接合培地を入れた. 2 日後には有性生殖の反応が見ら れたので, マイクロピペットで吸い取り, 片つ端から写真 を撮った．精子束がメス群体にたどり着くと, バラバラと
なり個々の雄性配偶子になるのであるが, ユードリナやボ ルボックスのようにメス群体に侵入することはなかった(図 6B-E). 驚くことに雌性配偶子がメス群体から泳ぎ出て, 体外で雄性配偶子と接合し, 網目模様の細胞壁をもつ休眠 接合子となった (図6F-L).「体外受精タイプの異型配偶子 接合」であった。これまでに, 群体性ボルボックス目では 培養材料では報告されていないタイプの有性生殖であった (Nozaki et al. 2014). 接合子発芽は後でやろうと思い, 11 月に有性生殖の誘導実験を再開した。しかし, 精子束は形 成されるが, 接合子は全く形成されなかった。培養株確立 直後は有性生殖が容易に誘導されたが，3-4 ケ月で接合し なくなるようであった。「著しく急速に性発現が減衰する 生物」が “Yamadiella”であった. 有性生殖の写真撮影に「こ の次やろう」はない.「やっている時になるべく多くの写真 を撮るべし」であった。

我々は“Yamadiella”をボルボックス科の新属コルマノス ファエラ (Colemanosphaera) として記載した (Nozaki et al. 2014). 本属は, 32 細胞性である点, 回転楕円体の栄養群 体を持ち, 非生殖細胞の分化が認められない点でボルボッ

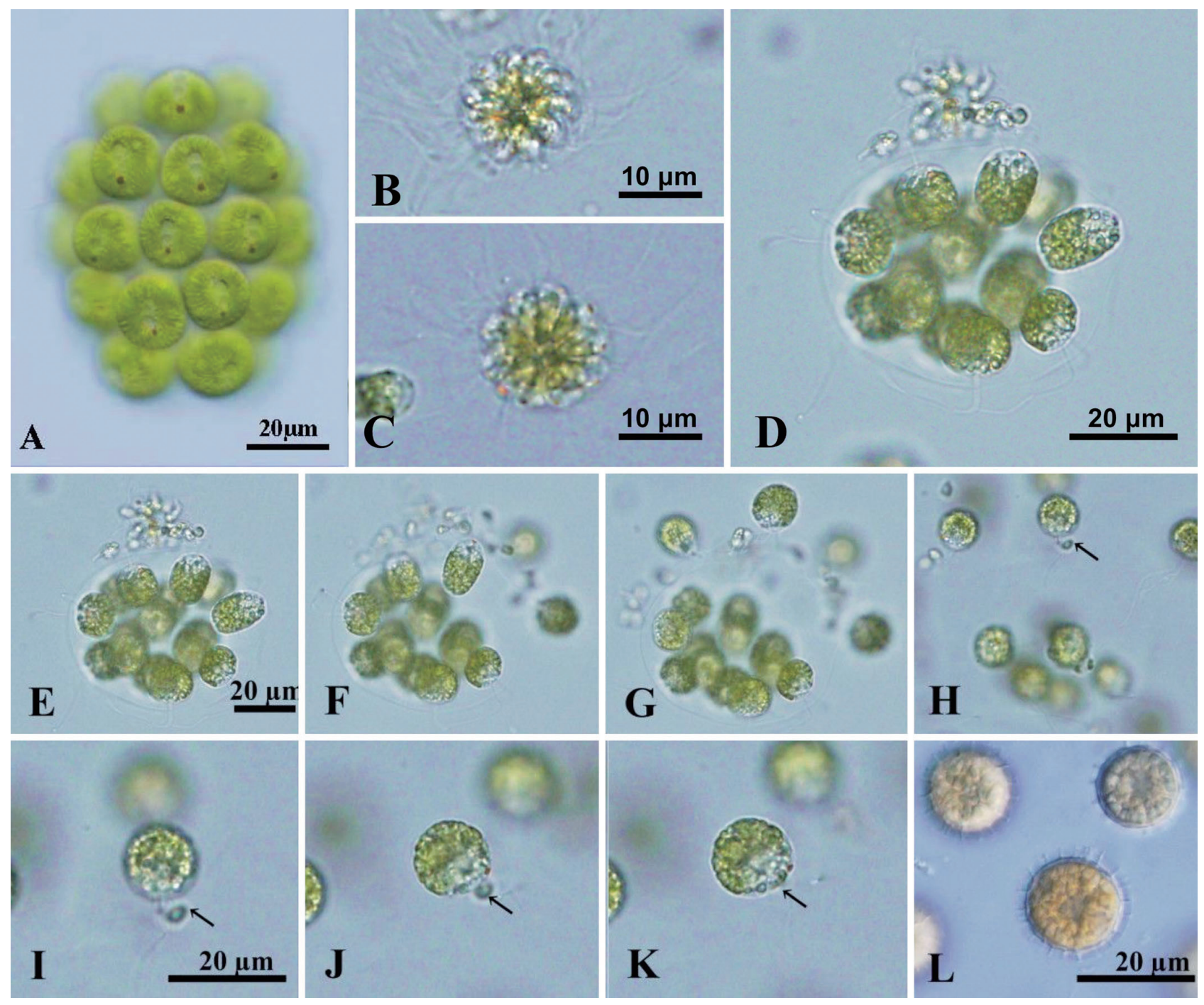

図6 群体性ボルボックス目のミッシグリンク新属コルマノスファエラ(Colemanosphaera) (Nozaki et al. 2014). F-H, I-Kはそれぞれ同一倍率。 (A) C. charkowiensis の 32 細胞性の栄養群体. (B-L) C. charkowiensisの有性生殖. (B, C) 雄性配偶子の群体 (精子束). (D-K) 雌雄配偶子の体外 受精過程. 矢印は接合している雄性配偶子。（L)成熟した休眠接合子.すざてNozakiら (2014)より転載した. 


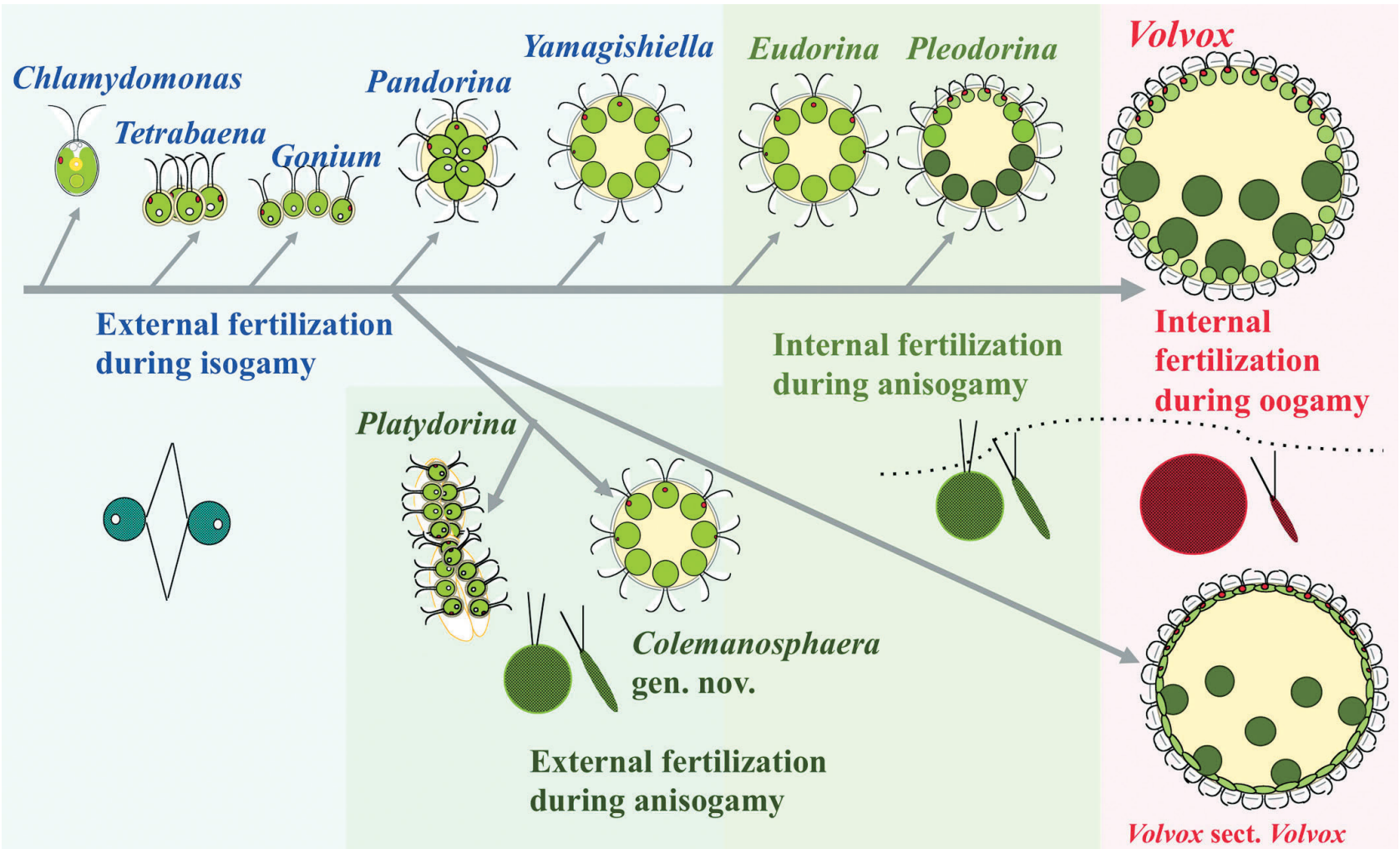

図7 群体性ボルボックス目のミッシグリンク新属コルマノスファエラ(Colemanosphaera) の系統的位置 (Nozaki et al. 2014). 図は Nozaki ら (2014)より転載, 改変した.

クス科のユードリナやヤマギシエラと類似するが, 栄養細 胞の収縮胞と葉緑体のピレノイドの形態的特徴では区別さ れた。葉緑体 5 遺伝子系統解析の結果では, コルマノスフ アエラはプラチドリナと強固な単系統群を形成した。 また, コルマノスファエラの細胞形態や，特異な体外受精型の異 形配偶接合過程は，プラチドリナ(採集サンプルで体外受 精観察が報告されている, Taft 1940) と類似していた(図 7). これらの結果から, 新属コルマノスファエラは, プラチド リナが平板群体に進化する直前の祖先的な形態を保持して いる“ミッシングリンク”であると考えられた。コルマノス ファエラは稀産であるが，過去の DNA配列データや形態 学的記載と今回の培養株を比較したところ, ヨーロッパに も2種分布することが明らかであった (Nozaki et al. 2014).

ボルボックスに進化する直前の生物も最近タイから採取 された. 2 鞭毛型の遊泳細胞が集合し, 多細胞化したボル ボックス系列の最も進化段階の高いものがボルボックス属 で，その直前がプレオドリナ属と伝統的に考えられてい る。ボルボックスは500以上の細胞をもち, 非生殖細胞が 球体の前端から後端までほぼ均一に分布しているが，プレ オドリナは細胞数が 200 以下で非生殖細胞は球体の前半だ けに通常分布する。しかし, Pleodorina sphaericaは通常のボ ルボックスと同様に球体の前端から後端まで非生殖細胞が 均等に分布するが，細胞数は 200 未満であるという両属の 中間的な形態をもち，ボルボックスの祖先的な種であると 議論されていた (Iyengar 1933)。これまでに本種はインド から 2 回報告されただけであり，1951年以来採集記録もな かった (Iyengar and Ramanathan 1951)。我々は65年ぶり にタイ王国からP. sphaerica 採集し(図7), 確立した培養
株を用いて分子系統学的解析を実施した。その結果，本種 は非生殖細胞が群体の前半だけに分布する他の種のプレオ ドリナ (P. californica, P. japonica) の姉妹種であることが明ら かになった。これら 3 種のプレオドリナはボルボックッス 8 種と大きな単系統群を形成し, その末端の系統に位置し た. 従って, P. sphaericaはボルボックスの祖先種というょり, プレオドリナの祖先種である可能性が議論された (Nozaki et al. 2017).

世界の淡水域，特に熱帯には，未発見の生物がまだまだ 沢山存在すると考えられる。今後, 更なるミッシングリン クを求めて調查して, ライフサイクルの誘導と形態観察を 実施して行きたい。
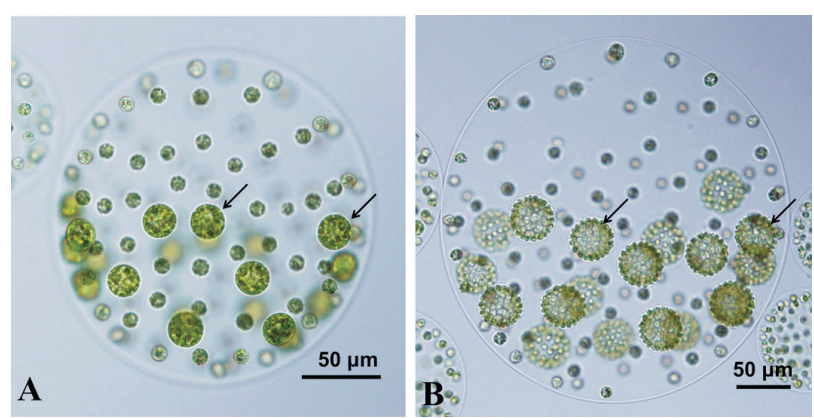

図8 65 年ぶりで再発見されたボルボックス (Volvox) の直接の祖 先種と考えられたプレオドリナの 1 種 (Pleodorina sphaerica) (Nozaki et al. 2017). (A) 栄養群体. ボルボックス sの大きな生殖細胞 (矢印) が小さな非生殖細胞の位置に介在するが, 細胞数は 200 以下である. (B) 無性生殖. 生殖細胞は分裂して娘群体 (矢印)になる。写真 (A, B) はNozaki ら (2017) から転載した. Phycologiaの転載許可 (Copyright Clearance Centre の License Number 4460240488168)による. 


\section{謝辞}

1977 年の学部卒業研究から一貫して藻類の形態学的研 究ができたのも様々な方々, 特に研究指導をして下さった 先生方, 職場の皆様, 共同研究者, 現地の研究協力者, 現 旧の学生の方々の廕と思い, 感謝しています。 また, 新 垣陽子博士 (株式会社バイオジェット) には図の借用で大 変お世話になっています。

\section{引用文献}

Arakaki, Y., Kawai-Toyooka, H., Hamamura, Y., Higashiyama, T., Noga, A., Hirono, M., Olson, B. J. S. C., and Nozaki, H. (2013) The simplest integrated multicellular organism unveiled. PLoS ONE 8: e81641. doi:10.1371/journal. pone.0081641.

Arakaki, Y., Fujiwara, T., Kawai-Toyooka, H., Kawafune, K., Featherston, J., Durand, P. M., Miyagishima, S., and Nozaki, H. (2017) Evolution of cytokinesis-related protein localization during the emergence of multicellularity in volvocine green algae. BMC Evol Biol 17: 243. https://doi. org/10.1186/s12862-017-1091-z.

新垣陽子, 豊岡博子, 野崎久義. (2013) 世界最小の多細 胞生物の発掘 -4 細胞で 2 億年間ハッピーな生きた化 石 “しあわせ藻” - 東京大学理学部・理学系研究科 70 レスリリース 2013/12/12 <https://www.s.u-tokyo.ac.jp/ $\mathrm{ja} /$ press/2013/47.html >.

Chong, J., Jackson, C., Kim, J. I., Yoon, H. S., and Reyes-Prieto, A. (2014) Molecular markers from different genomic compartments reveal cryptic diversity within glaucophyte species. Mol Phylogenet Evol 76:181-188.

Coleman, A. W. (1959) Sexual Isolation in Pandorina morum. $J$ Protozool 6: 249-264.

Featherston, J. Arakaki, Y., Hanschen, E. R., Ferris, P. J., Michod, R. E., Olson, B. J. S. C., Nozaki, H., and Durand, P. M. (2018) The 4-celled Tetrabaena socialis nuclear genome reveals the essential components for genetic control of cell number at the origin of multicellularity in the volvocine lineage. Mol Biol Evol 35: 855-870.

Ferris, P., Olson, B. J. S. C., De Hoff, P. L., Douglass, S., Casero Diaz-Cano, D., Prochnik, S., Geng, S., Rai, R., Grimwood, J., Schmutz, J., Nishii, I., Hamaji, T., Nozaki, H., Pellegrini, M., and Umen, J. G. (2010) Evolution of an expanded sex determining region in Volvox. Science 328: 351-354.

Hamaji, T., Kawai-Toyooka, H., Uchimura, H., Suzuki, M., Noguchi, H., Minakuchi, Y., Toyoda, A., Fujiyama, A., Miyagishima, S., James G. Umen, J. G., and Nozaki, H. (2018) Anisogamy evolved with a reduced sex-determining region in volvocine green algae. Comms Biol 1:17. doi:10.1038/s42003-018-0019-5.

浜地貴志, 豊岡博子, 豊田敦, 野崎久義. (2018) 最初の才 スとメスを生み出した性染色体領域を全ゲノム解読か ら解明 —“アダム”を作った小さな設計図“OSU” の発 見一 東京大学理学部・理学系研究科プレスリリース 2018/03/08 <http://www.s.u-tokyo.ac.jp/ja/info/5786/>.

Hanschen, E. R., Marriage, T. N., Ferris, P. J., Hamaji, T., Toyoda, A., Fujiyama, A., Neme, R., Noguchi, H.,
Minakuchi, Y., Suzuki, M., Kawai-Toyooka, H., Smith, D. R., Sparks, H., Anderson, J., Bakarić, R., Luria, V., Karger, A., Kirschner, M., Durand, P. M., Michod, R. E., Nozaki, H., and Olson, B. J. S. C. (2016) The Gonium pectorale genome demonstrates cooption of cell cycle regulation during the evolution of multicellularity. Nature Commun 7: 11370. doi:10.1038/ncomms 11370 .

Herron, M. D., Hackett, J. D., Aylward, F. O., and Michod, R. E. (2009) Triassic origin and early radiation of multicellular volvocine algae. Proc Natl Acad Sci USA 106: 3254-3258.

Hong, Z., Geisler-Lee, C. J., Zhang, Z., Verma, D. P. S. (2003) Phragmoplastin dynamics: multiple forms, microtubule association and their roles in cell plate formation in plants. Plant Mol Biol 53: 297-312.

市村輝宣.（1971-1973）微細藻類の培養に関するあれこれ. (1) - (6) 遺伝 25 (12): 69-72; 26 (1): 97-100; 26 (2): 73-77; 27 (2): 62-66; 27 (3): 64-68; 27 (4): 97-101.

Isaka, N., Kawai-Toyooka, H., Matsuzaki, R., Nakada, T., and Nozaki, H. (2012) Description of two new monoecious species of Volvox sect. Volvox (Volvocaceae, Chlorophyceae), based on comparative morphology and molecular phylogeny of cultured material. J Phycol 48: 759-767.

Iyengar, M. O. P. (1933) Contributions to our knowledge of the colonial Volvocales of South India. J Linn Soc London Bot 49: 323-375.

Iyengar, M. O. P. and Ramanathan, K. R. (1951) On the structure and reproduction of Pleodorina sphaerica Iyengar. Phytomorphology 1: 215-224.

Kirk, L. D. (2005) A twelve-step program for evolving multicellularity and a division of labor. Bioessays 27: 299310 .

Nozaki, H. (1986) Sexual reproduction in Gonium sociale (Chlorophyta, Volvocales). Phycologia 25: 29-35.

Nozaki, H. (1994) Aplanogamous sexual reproduction in Carteria eugametos (Volvocales, Chlorophyta). Eur J Phycol 29: 135-139.

Nozaki, H., Aizawa, K., and Watanabe, M. M. (1994) A taxonomic study of four species of Carteria (Volvocales, Chlorophyta) with cruciate anterior papillae, based on cultured material. Phycologia 33: 230-247.

Nozaki, H. and Ito, M. (1994). Phylogenetic relationships within the colonial Volvocales (Chlorophyta) inferred from cladistic analysis based on morphological data. J Phycol 30: 353-365.

Nozaki, H., Ito, M., Watanabe, M. M., Takano, H., and Kuroiwa, T. (1997) Phylogenetic analysis of morphological species of Carteria (Volvocales, Chlorophyta) based on $r b c L$ gene sequences. J Phycol 33: 864-867.

Nozaki, H. and Kasaki, H. (1979) The sexual process of Japanese Pandorina morum Bory (Chlorophyta). J Jpn Bot 54: 363-370.

Nozaki, H. and Kuroiwa, T. (1992) Ultrastructure of the extracellular matrix and taxonomy of Eudorina, Pleodorina and Yamagishiella gen. nov. (Volvocaceae, Chlorophyta). Phycologia 31: 529-541.

Nozaki, H., Misawa, K., Kajita, T., Kato, M., Nohara, S., and 
Watanabe, M. M. (2000) Origin and evolution of the colonial Volvocales (Chlorophyceae) as inferred from multiple, chloroplast gene sequences. Mol Phylog Evol 17: 256-268.

Nozaki, H., Mahakham, W., Athibai, S., Yamamoto, K., Takusagawa, M., Misumi, O., Herron, M. D., Rosenzweig, F., and Kawachi, M. (2017) Rediscovery of the 'ancestral Volvox' species: morphology and phylogenetic position of Pleodorina sphaerica (Volvocales, Chlorophyceae) from Thailand. Phycologia 56: 469-475.

Nozaki, H., Mori, T., Misumi, O., Matsunaga, S., and Kuroiwa, T. (2006) Males evolved from the dominant isogametic mating type. Curr Biol 16: R1018-R1020.

Nozaki, H., Ohta, N., Morita, E., and Watanabe, M. M. (1998) Toward a natural system of species in Chlorogonium (Volvocales, Chlorophyta): a combined analysis of morphological and $r b c L$ gene sequence data. $J$ Phycol 34: 1024-1037.

Nozaki, H., Yamada, T. K., Takahashi, F., Matsuzaki, R., and Nakada, T. (2014) New "missing link" genus of the colonial volvocine green algae gives insights into the evolution of oogamy. BMC Evol Biol 14: 37. doi: 10.1186/1471-2148-1437.

野崎久義. (1986) 群体性オオヒゲマワリ目 (緑藻植物) の 有性生殖. 藻類 34: 232-247.

野崎久義. (1995a) 群体性ボルボックス目 (緑藻植物) の系 統 ——形態学と塩基配列からの両アプローチ. Plant Morphol 7: 19-27.

野崎久義. (1995b) “币型” の前端パピラをもつ Carteria（緑 藻, オオヒゲマワリ目) の有性生殖と分類・系統. 藻 類 43: 103-114.

野崎久義.（1998）微細藻類の種レベルの自然分類体系に 向けて:形態とDNA 塩基配列データを結合させた解析. Microbiol Cult Coll 14: 39-48.

野崎久義.（2008） はじめて明らかになった雌雄の起源〜 群体性ボルボックス目のオス特異的遺伝子 “OTOKOGI”. Plant Morphol 19: 55-64.

野崎久義. (2010) 淡水藻類の一分類学者の軌跡 “時の流れ に身をまかせて”。Bunrui 10: 97-115.

Stein, J. R. (1959) The four-celled species of Gonium. Am J Bot 46: 366-371.

Sugasawa, M., Matsuzaki, R., Arakaki, Y., and Nozaki H. (2015) Morphology and phylogenetic position of a rare four-celled green alga, Pascherina tetras (Volvocales, Chlorophyceae), based on cultured material. Phycologia 54: 342-348.

Taft, C. E. (1940) Asexual and sexual reproduction in Platydorina caudata Kofoid. Trans Am Microscop Soc 59: 1-11.

Takahashi, T., Sato, M., Toyooka, K., Matsuzaki, R., Kawafune, K., Kawamura, M., Okuda, K., and Nozaki, H. (2014) Five Cyanophora (Cyanophorales, Glaucophyta) species delineated based on morphological and molecular data. $J$ Phycol 50: 1058-1069.

Takahashi, T., Nishida, T., Tuji, A., Saito, C., Matsuzaki, R., Sato, M., Toyooka, K., Yasuda, H., and Nozaki, H. (2016) Delineation of six species of the primitive algal genus
Glaucocystis based on in situ ultrastructural characteristics. Sci Rep 6: 29209. doi: 10.1038/srep29209.

高橋紀之, 野崎久義.（2016）微細構造の三次元的な理解 による灰色植物の分類体系の実現を目指して. Plant Morphol 29 : 49-54.

Yamamoto, K., Kawai-Toyooka, H., Hamaji, T., Tsuchikane, Y., Mori, T., Takahashi, F., Sekimoto, H., Ferris, J. P., and Nozaki, H. (2017) Molecular evolutionary analysis of a gender-limited MID ortholog from the homothallic species Volvox africanus with male and monoecious spheroids. PLoS ONE 12: e0180313. doi: /10.1371/journal.pone.0180313. Received: 15 November 2018 / Accepted: 26 February 2019 